\title{
DESCRIPTION OF A NEW SPECIES OF OPHICHTHYS (OPHICHTHYS RETROPINNIS), FROM PENSACOLA, FLA.
}

\section{BY CARL H. EIGENIIANN.}

Ophichthys retropinnis, sp. nov.

This species is most nearly related to O. ocellatus and O.guttifer. It can be distinguished from these and all other described American species of Ophichthys by the posterior insertion of the dorsal fin.

- Head pyramidal, flattened above, tapering from the occiput to the pointed snout. Mouth very large, the cleft about 3 in head. A single series of irregular teeth in the mandible, those forward larger; two small canines behind this series in front. Maxillaries with two distinct series of smaller teeth; premaxillaries with a single series of teeth. Vomer with about 15 teeth, the first two side by side, the others in a single series; the third (first in single series) largest. Eye elongate, rather large, $1 \frac{1}{3}$ in snout, equal to the interorbital width. Gill-opening 5 in head. Pectorals well developed (measured from the upper margin of their base to the tip of the longest ray), $2 \frac{1}{2}$ in the distance from the snout to their base. Dorsal inserted $1 \frac{1}{5}$ length of pectorals behind the tips of the pectorals; the distance from its insertion to the gill-opening slightly more than length of head. Head 9 in length.

Color faded in spirits, apparently light olivaceous, with about $20 \mathrm{ob}$ long dark blotches along the median line of the body and tail ; the interspaces between these, each a round pale spot about as large as eye; the dark spots about twice as long; a dark bar behind cheek; a black point below middle of eye ; three points in a vertical series behind eye and three on top of the head; one a little behind the vertical series of spots and one above the posterior part of each eye.

A single specimen taken from the stomach of some other fish was sent by Mr. Silas Stearns to the museum of the Indiana University and has now been deposited in the U.S. National Museum. (No. 38054.)

Length, $20 \frac{7}{8}\left(9 \frac{3}{4}+11 \frac{1}{8}\right)$ inches; distance from snout to dorsal, $5 \frac{1}{8}$ inches. INDIANA UNIVERsiTy, February 12, 1887. 


\section{$2 \mathrm{BHL}$ Biodiversity Heritage Library}

Eigenmann, Carl H. 1887. "Description of a new species of Ophichthys (Ophichthys retropinnis), from Pensacola, Fla." Proceedings of the United States National Museum 10(613), 116-116. https://doi.org/10.5479/si.00963801.10-613.116.

View This Item Online: https://www.biodiversitylibrary.org/item/32314

DOI: https://doi.org/10.5479/si.00963801.10-613.116

Permalink: https://www.biodiversitylibrary.org/partpdf/23716

\section{Holding Institution}

Smithsonian Libraries

\section{Sponsored by}

Smithsonian

\section{Copyright \& Reuse}

Copyright Status: NOT_IN_COPYRIGHT

This document was created from content at the Biodiversity Heritage Library, the world's largest open access digital library for biodiversity literature and archives. Visit BHL at https://www.biodiversitylibrary.org. 